\title{
BUILDING A DISCIPLINE. THE SETUP OF COMMUNICATION AS AN ACADEMIC DISCIPLINE IN ROMANIA
}

\author{
Corina Buzoianu \\ National University of Political Studies and Public Administration \\ corina.buzoianu@comunicare.ro \\ Monica Bira \\ National University of Political Studies and Public Administration \\ monica.bira@comunicare.ro \\ Alina Duduciuc \\ National University of Political Studies and Public Administration \\ alina.duduciuc@comunicare.ro
}

\begin{abstract}
This paper aims to shed a light on the importance of looking on the epistemological and methodological grounds of communication as a discipline in Romania in order to be able to discuss about the professionalization of the domain. We start from the widely acknowledged idea that communication is a new and emerging field, drawing its concepts, theories, and methods from diverse other fields and domains. In Romania, as well as in other former communist countries, after 1990 the changes in the political and economic situation created the premises to establish university programs in communication and to create jobs for people working in communication. All these were possible with the help of "imports" from the Western world, imports that transferred not only concepts and theories, but also the epistemological dispute and weakness of the field. This paper explores the development and the current state of communication as an academic discipline in Romania. Through an analysis of the social documents available on the University program's website, we seek to understand the theoretical roots of the discipline of communication, as well as its current development.
\end{abstract}

\section{Keywords}

communication; building a discipline; communication in Romania; academic discipline

\section{JEL Classification}

M41

\section{Communication as a discipline in South Eastern Europe}

When compared with other social disciplines, communication is an emerging field facing a rapid development through academic research and publications, academic programs, international academic associations, and professional associations (Wang, 2011; Taylor \& Lindlof, 2013). As the literature on the field widely mentions, communication has drawn concepts and knowledge from a great variety of areas (Casmir, 2012) and is, thus, uncomfortable in articulating a solid identity (Craig, 1999). The interdisciplinary trends have had a great influence on the development of communication thus leading to the current diversity of theories in communication. All these led to the necessity to look at communication and its epistemological roots in order to fully understand its setup as a discipline. Some scholars suggest that metatheory should be used in order to reach a critical understanding of the diversity of theories of communication (Craig, 2013). 
As a consequence of its diversity and interdisciplinary grounds, researchers divide communication in subfields (Lindlof \& Taylor, 2011) to distinguish between the theories and approaches in communication. The multi- and interdisciplinary character of communication is seen both as a source of incoherence and as one of its meritorious qualities (Craig, 1999; 2013). As in the case of every new field, communication scholars did not reach paradigmatic consensus and common understanding of communication theory as a field (Craig, 1999; Taylor \& Lindlof, 2013). Some scholars (Sfez, 2001), when referring to a nucleus specific to communication, question the possibility for communication to become a science, meanwhile others (Craig, 2009, 9) are, on the contrary, arguing that cultivating theoretical cosmopolitanism is a practical suggestion for anyone who would like to contribute to a field of communication theory. There is a large body of literature on the development of communication as a field in the "Western" world (McQuail, 2008; Simonson \& Park, 2015), as current literature mainly maps communication studies in North-American and Western European countries. Although there are several studies dealing with communication and journalism in former communist countries (Jirak \& Kopplova, 2008; Klyukanov, 2011; Casmir, 2012; Ivan, Daba-Buzoianu \& Gray, 2014; Peruško \& Vozab, 2015), few studies that we know about approach the development of communication as a field in Eastern European countries. Thus, we know little about the theories and paradigms that grounded communication in former communist countries. In Eastern Europe, the development and institutionalization of communication started after the fall of communism and continues today (Simonson \& Park, 2015; Casmir, 2012). Communication developed in former communist countries with the help of "imports" from the North-American and Western European epistemologies, as the mainstream communication theory is still limited to the American and Eurocentric cultural assumptions (Craig, 2009). After 1990, Romania and other countries in Eastern Europe faced a shift in the social sciences, as many university study programs were established, including communication. When "importing" the field of communication, Eastern European scholars acknowledged the dispute regarding the core theories of communication, a fact that continues to have an impact on the development of the field of communication.

Looking at the current research of the field we identify four gaps that are essential to the setup of communication as a discipline, especially in Romania and other South European Countries. The first gap is linked to the university programs in communication, as there is no research available on the way communication programs are being structured in Romania. One can hardly find details about the specificity of Romanian academic programs in the field of communication and the theoretical and methodological similarities between the programs in communication in Romania and Western European Universities. We consider this an important gap especially in the context of the Bologna process, where equivalence of diplomas implies equivalence of competences. Although there are studies regarding the development of the higher education system in Romania and other Eastern European countries (Sadlak, 1993), these studies do not include the communication domain and the way this filed is constituted as an academic field. The second gap identified in the current literature is the apparent lack of interest for issues related to the academic training of professionals in communication. Large scale studies keep a focus on future trends, the use of technologies and innovation and do not gather detailed data to provide an insight on the academic background of communication professionals. For example, the European Communicator Monitor, the largest transnational study on strategic communication worldwide, conducted annually since 2007, inquires only about the degree level of professionals in communication, but not about their degree specialization (European Communicator Monitor, 2009-2016). Moreover, a study based on a survey of 1401 communication professionals from 30 European countries shows that $27 \%$ of the 
participants have a degree in communication (Beurer-Zuelling, Fieseler \& Meckel, 2009). The third gap identified in the existent literature is the role that professional associations in communication have in Eastern Europe. As shown in the European Communicator Monitor (2009-2016), there is an increasing importance of professional associations in communication. The mere fact that a question about being a member of a professional association is included in this large-scale survey offers a valuable insight as to where (symbolic) professional recognition may lay. For the Romanian case, we must keep in mind that professional associations in communication (e.g. ARRP, CCRP) had to face challenges specific to a post-communist society like trying to develop a proper NGO sector and avoiding to be associated with the "dusty" reputation of unions. The fourth gap refers to a practical question: in Romania, tracing the careers of university graduates is left to the appreciation of each university or faculty. Therefore, every institution keeps its own records; data are seldom exploitable beyond bureaucratic objectives. Universities lack tools for tracking the short and mid-term evolution of any field, communication included, by looking into the career paths and employment patterns of graduates.

To this, it is worth mentioning that after the fall of the communism, in Romania, some other challenges occurred. For example, in the early ' 90 s, few scholars in Romania could read in English, as this language was less taught in school during the communist regime. The first scholars teaching communication grounded their teaching in other epistemologies, like philosophy, humanities, and sociology. Secondly, when the first job positions in communication became available in Romania, people with no previous experience or academic background in communication were hired. These issues are persisting today, as many job adverts in communication require a university degree, but not explicitly a degree in communication, especially for mid-senior and senior level, as might be proved by a quick visit on any popular job finder website in Romania.

This paper is the result of the first phase study of a research project aiming to analyze the way communication as a field is established in Romania, by exploring its epistemological grounds, the research methodologies and the overall development of communication as a discipline in Romania. In doing so, we put under scrutiny the professionalization of the field of communication in Romania, by considering in Craig's terms (1999) that a clear theoretical ground and a paradigmatic consensus would lead to a deeper understanding of the identity of the communication field. Thus, solid communication study programs, together with a profound inquiry of the way communication is being perceived will lead to the further development of the field and to its professionalization. For professionals in social sciences it is useful to scrutinize their own domain, from time to time, and to question their role in society and as far as we know, there is a lack of scientific studies approaching the way in which communication as a field is structured in Romania. The originality of our research lies precisely in the effort to assess the perceptions and routes in the communication field, not only from an epistemological point of view, but also from a perspective that will bridge academia with labor market.

The main objective taken by this paper is the assessment of the Romanian study programs in communication and the content, both in terms of numbers (how many programs are available at a national level; what the existing degree levels are; how many students attend the programs) and content (what disciplines are included in the curricula; what thesis subjects are defended). We aim to inquire the epistemological perspectives of the said institution's study program in communication through an analysis of their approach of communication-related disciplines. 


\section{Method of the study}

The research project underpinning this paper is based on a qualitative approach, using social documents analysis to explore the development and current state of University programs in communication in Romania. The social document analysis provides the foundation for the research project by investigating the undergraduate and graduate programs in communication at the university level. A convenience sample was considered in our case. As The Romanian Agency for Quality Assurance in Higher Education (ARACIS) regulates, the domain is referred to as communication science and undergraduate study program can be established: journalism, communication and public relations, advertising, information and documentation sciences, digital media and communication and emerging media.

The main criteria used for the sample was the existing bachelor program in communication science, as required by ARACIS. We selected three major university centers from three different sides of Romania (Bucharest, Cluj, Iasi) and three smaller university centers (Bacau, Sibiu, Craiova), aiming to cover all parts of the Romanian university landscape. We decided not to increase the number of Universities for our sample for this stage of the research due to the difficulties in finding data available on the websites and to expand our sample in the next steps, when we intend to contact the administration of the university and ask for the documents. We gathered all the relevant data available on the websites and analyzed the following documents and sections: (1) academic curricula of the study program for students to graduate in 2020 (in the case they were not available we considered the ones from the previous years, but not older than 2015); (2) academic and professional path of the teaching staff with a permanent contract (treatment of data was difficult in this case as information regarding these aspects are hard to find); (3) self-presentation of the program on the website (history, mission, vision and values); (4) syllabus for the courses in the curricula (most the of syllabus were not available and data from the syllabus was archived but considered in this stage of the research); (5) contextual factors shaping the particularities for each selected program (as for example the faculty which hosts the program or the type of accreditation received after formal evaluation). From the above mentioned elements, in this paper we focus mainly on the statements about history, mission, vision and values and on the curricula available for communication programs, mainly courses that are not mandatory and are not due to compulsory regulation of ARACIS (The Romanian Agency for Quality Assurance in Higher Education). First, we were interested in the statements about the program as the bases of understanding the overall epistemological and methodological grounds and in identifying the linkage with different theories of communication and labor market. Second, we looked at the courses that are not listed by ARACIS as mandatory in order to see how the academic programs offers subjects linked to the labor market or to other related social sciences disciplines. This was looked into by also considering the educational and professional path of the teaching staff.

\section{Main findings}

As part of a research project aiming to look at the epistemological grounds of communication in Romania and at the setup of the discipline in academia, this paper presents the preliminary findings based on the first phase of the research. We organized our key findings around three focal points, aiming to shed a light on (1) how communication studies are organized from an institutional viewpoint, (2) the discourse they share about values, relevance and institutional achievements and (3) to examine the development of the domain looking into the academic path followed by the university staff. 


\section{Communication studies and institutional affiliation}

It is not a new thing to say that communication, as so many other recent additions to university curricula, has emerged as an academic discipline roughly 30 years ago. Without dwelling upon the economic and social changes shaped Romanian universities since then, when looking at the timeline of the institutionalization of communication studies one may easily observe that although the first steps took place at the beginning of the 1990's, it is only ten years later when communication studies became an established field from an administrative viewpoint. Drawing from our data we see that many BA programs in communication are missing from the timeline below, especially when it comes to smaller university centers. In a broader perspective this makes sense: as we shall see further down our study. The cultivation of an institutional memory seems to be the hallmark of universities from larger cities.

Table 1: A timeline of communication study programs

\begin{tabular}{|c|c|c|c|c|}
\hline Year & BA & PhD & $\begin{array}{l}\text { Larger } \\
\text { university } \\
\text { centers }\end{array}$ & $\begin{array}{l}\text { Smaller } \\
\text { university } \\
\text { centers }\end{array}$ \\
\hline \multicolumn{5}{|l|}{1990} \\
\hline 1993 & $\begin{array}{l}\text { establishment of the Department of Communication } \\
\text { and PR within The Faculty of Letters (University of } \\
\text { Bucharest) }\end{array}$ & & $\begin{array}{l}\text { University of } \\
\text { Bucharest }\end{array}$ & \\
\hline 1995 & $\begin{array}{l}\text { establishment of the Faculty of Political sciences, } \\
\text { Administration and Communication (FSPAC) } \\
\text { University of Cluj }\end{array}$ & & $\begin{array}{l}\text { University of } \\
\text { Cluj }\end{array}$ & \\
\hline 1998 & $\begin{array}{l}\text { establishment of a BA study program on } \\
\text { communication and PR, within the National School } \\
\text { of Political Studies and Administration in Bucharest }\end{array}$ & & $\begin{array}{l}\text { SNSPA - } \\
\text { Bucharest }\end{array}$ & \\
\hline 2001 & $\begin{array}{l}\text { establishment of a BA study program on } \\
\text { communication and PR within the Department of } \\
\text { Communication PR and Advertising at FSPAC - } \\
\text { UBB Cluj }\end{array}$ & & $\begin{array}{l}\text { University of } \\
\text { Cluj }\end{array}$ & \\
\hline 2002 & $\begin{array}{l}\text { establishment of a BA study program within the } \\
\text { Faculty of Social and Political Sciences (FSSP) } \\
\text { within the University of Iasi }\end{array}$ & & $\begin{array}{l}\text { University of } \\
\text { Iasi }\end{array}$ & \\
\hline 2002 & \multicolumn{2}{|l|}{$\begin{array}{l}\text { establishment of a BA study program within the } \\
\text { University of Craiova }\end{array}$} & & $\begin{array}{l}\text { University } \\
\text { of } \\
\text { Craiova }\end{array}$ \\
\hline 2008 & \multicolumn{2}{|c|}{$\begin{array}{l}\text { establishment of a PhD study program in } \\
\text { Communication, within SNSPA }\end{array}$} & $\begin{array}{l}\text { SNSPA - } \\
\text { Bucharest }\end{array}$ & \\
\hline 2014 & \multicolumn{2}{|c|}{$\begin{array}{l}\text { establishment of a PhD study program in } \\
\text { Communication, within FSPAC, University } \\
\text { of Cluj }\end{array}$} & $\begin{array}{l}\text { University of } \\
\text { Cluj }\end{array}$ & \\
\hline 2019 & & & & \\
\hline
\end{tabular}

Since communication studies were established within pre-existing academic structures, it follows that, at least in its beginning, the domain was - from an administrative and institutional viewpoint - close to other academic disciplines and molded into institutional forms that could fit the administrative requirement of the day. The current situation of faculties and departments proposing BA study programs in communication sciences is a reflection of those beginning as well as the consequence of institutional development and demographic changes in the area. 


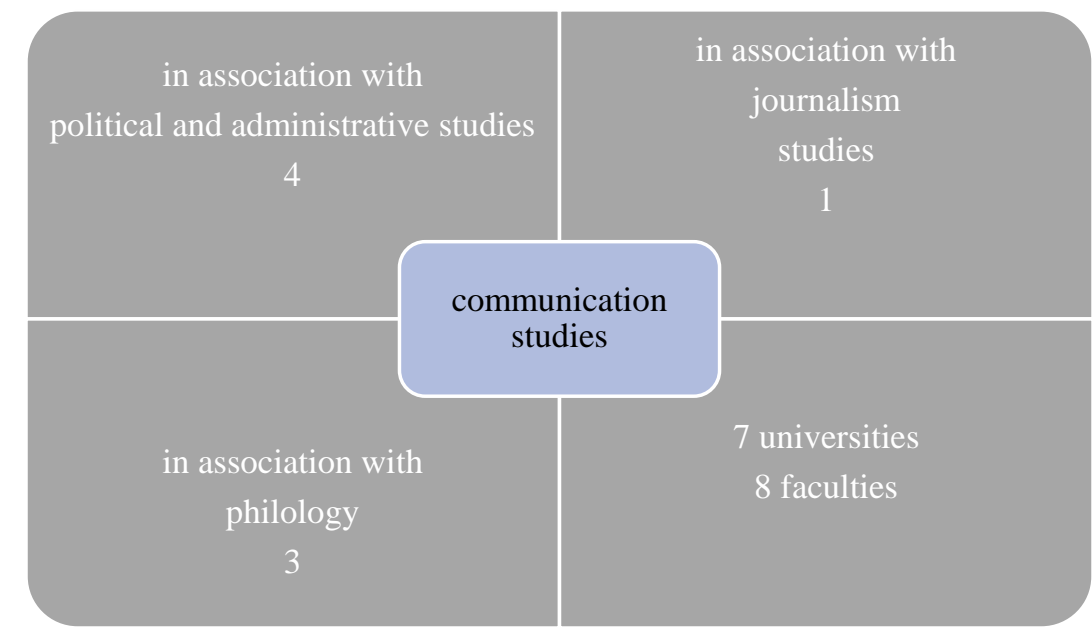

\section{Figure 1: An overview of academic disciplines related to communication studies from an institutional viewpoint}

As it shows in the chart above, there are three major academic domains within which communication sciences were adopted as BA discipline: social sciences (usually in close association with political sciences but not exclusively), journalism and philology. Usually, large university centers have more than one structure proposing a BA in communication sciences (as it is the case in Bucharest and Iasi), meanwhile smaller university centers usually have just one such structure.

The chart relies on the current institutional situation and on the information provided on their websites by faculties and departments proposing studies in communication in three major university centers (Bucharest, Cluj, Iasi) and in three smaller university centers (Bacau, Sibiu, Craiova). However, although the journalism and media studies seems to have an upper hand on the overall development of the communication in academia, available data points toward a shift within their formal training: the teaching staff that holds a BA in journalism (communication sciences) chose (or was forced to choose, due to the lack of available options) to continue the $\mathrm{PhD}$ studies in another domain, usually sociology or philology.

\section{Values and relevance}

A characteristic shared by all the university structures proposing BA study programs in communication that we explored within this article is the emphasis on the outcomes derived from this choice. Usually those outcomes are organized around two main topics: the competences acquired by graduates and their career options presented mainly through the form of enumerating jobs that require (according to the regulation) formal academic training in communication. There is little variation or creativity in this section of the website: the job denominations are those form the list provided by the national occupational qualifications index, although the workforce market, especially within the private sector, provides a larger array of job titles. Sometimes the solution of mentioning a larger activity domain is preferred to providing a list of possible future jobs: "our graduates (...) are working nowadays within editorial teams of numerous national and local publications, of various TV and radio broadcast companies, within publishing houses or departments of communication and public relations" (University of Sibiu).

The second common characteristic is to express the many ways in which the university and the staff is up to date with everything that may be correlated with modernity: a 
modern teaching approach and the opportunity to be involved in internships (with the most thought after employers) are values communicating by all the departments, in a variety of styles:

- The systemic study of communication is an imperative, as the proliferation of communication media has transformed the world where we live in a complex universe, deeply inter-connected (Faculty of Philosophy and Social Sciences, University of Iasi, 2019).

- Graduates of this specialization, extremely thought after on the workforce market, will be able to find a job in research institutions within the domain, PR and advertising agencies, departments of public communication within the central and local administration or within the corporate or NGO sector (Faculty of Letters, University of Bucharest, 2019).

- Our students are encouraged to think freely, to be creative and to present their opinions in an open, argumentative manner. (Department of Communication, PR and Advertising, University of Cluj, 2019).

As opposed to those two main themes shared across all the structures, when speaking about themselves faculties or departments of communication are also approaching themes that they consider to define their specificity and their unique selling point on the "market" of communication studies: pioneering and tradition. The tradition theme is to be found in the presentation of the communication program at the University of Bacau as well as the University of Sibiu: each of them are actually underlying the tradition of higher education in their respective cities, thus trying to convey a legitimacy for their more modern study domains, such as communication.

On the other hand, the pioneering is a theme disputed by all the 3 structures that are currently proposing a BA in communication in Bucharest: Faculty of Journalism and Faculty of Letters (the department of Communication and PR) and the Faculty of Communication and PR within SNSPA. Faculty of Journalism and the Department of Communication within the University of Bucharest are directly claiming to have been the first in their respective domains ("the first journalism faculty established after 1989" (Faculty of Journalism and Communication, University of Bucharest, 2019), "the first academic structure proposing communication studies at the University of Bucharest" (Faculty of Letters, University of Bucharest, 2019). The Faculty of Communication of PR within SNSPA has a different approach, aiming at the same legitimacy obtained via a pioneering tradition by proposing a timeline of the development of the faculty with references as early as 1991 (Faculty of Communication and PR, SNSPA, 2019).

\section{Humans of ... communication studies}

An academic discipline is obviously built not only around sharing and developing new ideas or testing new theories, but also around the people involved in this process. By looking into the academic path of the staff involved in teaching communication studies within seven university structures across the country, our aim was to bring into attention some characteristics related to age and academic formation of people shaping the actual communication domain within academia, that may contribute to a broader understanding of the current development of this domain. Further research will enlarge the database used and will also look into more characteristics than age and academic training (BA and $\mathrm{PhD})$.

Table 2: University staff teaching communication studies grouped by age

\begin{tabular}{|l|l|}
\hline Age & Number \\
\hline Under 30 & 2 \\
\hline $30-39$ years old & 27 \\
\hline
\end{tabular}




\begin{tabular}{|l|l|}
\hline $40-49$ years old & 37 \\
\hline $50-59$ years old & 12 \\
\hline Over 60 years old & 12 \\
\hline Total number of perused CV and self presentation: & 107 \\
\hline Total number of persons & $\mathbf{9 0}$ \\
\hline
\end{tabular}

As shown in the table below, we perused a total number of $107 \mathrm{CV}$ s and self presentations and as far as the age goes, our conclusions are only informed by 90 cases. The results are a mix between the state of communication as a "young" discipline in Romania and the current state of economic conditions related to jobs within academia. Therefore, the fact that only 2 persons out of 90 are under the age of 30 years old might be a consequence of the requirements that a young researcher must fulfill in order to land a fulltime job in academia (PhD degree) rather than anything else. The number of persons aged over 50 years old (24) is lower than any other age group and one may consider a correlation with the relatively "young age" of communication within universities.

Looking into the academic training of the staff that teaches and (and researches) within the communication domain, several characteristics are recurrent and we will present them without further elaboration, as we need more data in order to investigate eventual correlations or even causation.

The teaching staff, both from small universities and from larger ones tends to be the "product" of that same university, even of the same faculty. Smaller university centers tend to recruit their staff from their own graduates (BA level) meanwhile for $\mathrm{PhD}$ studies they are gravitating around a larger university center from the area (this is the case of Bacau University and Iasi University as well as for Sibiu University and the University of Cluj). Only 3 out of 90 persons included in the current study hold a $\mathrm{PhD}$ degree emanating from a university outside Romania, and none of them are within the field of communication studies, although many of the teaching staff had the opportunity to study abroad more than one month, usually during their PhD studies or post-doctoral studies, either in Europe or in USA (Fullbright).

The graphic below depicts the current situation of $\mathrm{BA}$ degrees and $\mathrm{PhD}$ degrees held by the staff employed within the faculties and departments of communication. Most of the staff involved in teaching communication disciplines were formally trained in philosophy, philology and sociology (across all the age groups) and communication studies (only for the younger generation). The category labeled as "other" includes study fields such as geography, theology, physics, engineering, economics and law: either for BA degrees or $\mathrm{PhD}$ degrees in those categories there were only one or two persons holding those specific degrees. Philosophy, philology and sociology have shaped the field of communication in its beginnings as an academic domain; nowadays, those three domains alongside communication studies are shaping the field of communication through their researches in terms of topics and methods. 


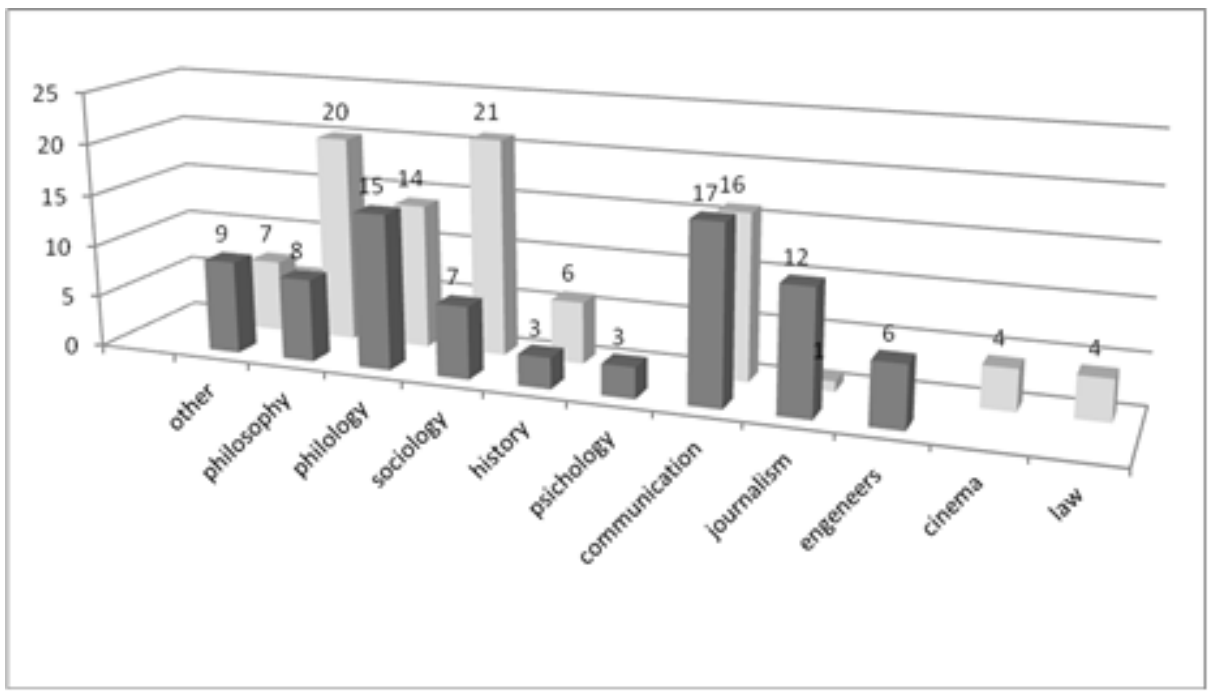

Figure 2: An overview of BA (dark grey) and PhD degrees (light grey) held by university staff teaching communication studies

\section{Conclusions}

Although based on preliminary findings, our study shows some very interesting results regarding the roots and the current development of academic programs in communication. First, data shows that the in Romania communication is not only following the multi- and interdisciplinary features of the domain, but also has been developed under other major academic domains. Thus, from the early beginning, Universities in Romania put communication in direct linkage with already known academic domains: social sciences (e.g. political sciences), philology and journalism. Second, the emergence of communication studies as an academic field is already producing consequences at the very level of the academic institutionalization of this new study domain: the younger generation of communication scholars is overwhelmingly trained within the very field they are shaping. Third, the dynamics of small and larger university centers seems to indicate the consolidation of several "centers of influence" in terms of scholarly approaches of communication: however, those centers are not limited to the "traditional" larger universities (in Bucharest, Cluj, and Iasi) as small university centers are developing alternative routes towards the consolidation of their status as competitive higher education institutions.

\section{References}

Beurer-Zuellig, B., Fieseler, C., Meckel, M. (2009), A descriptive inquiry into the corporate communication profession in Europe. Public Relations Review, 35, 3 , 270-279.

Casmir, F., L. (2012), Building Communication Theories: A Socio/cultural Approach, Routledge.

Craig, R. T., (1999), Communication theory as a field. Public Relations Review, 9, 119161.

Craig, R. T., (2009), Reflection on Communication Theory as a Field. Communiquer Revue de communication sociale et publique, 2, 7-12.

Craig, R. T. (2013), Constructing theories in communication research. In P. Cobley \& P. J. Schulz (Eds.), Theories and models of communication, Berlin / Boston: De Gruyter, 39-57. 
European Communication Monitor, (2016), retrieved from http://www.zerfass.de/ECM-WEBSITE/media/ECM2016-Results ChartVersion.pdf.

Faculty of Philosophy and Social Sciences, University of Iasi, (2019), available at URL https://www.fssp.uaic.ro/departamente/stiinte-ale-comunicarii-si-relatii-publice

Faculty of Letters, University of Bucharest (2019) available at URL https://litere.ro/studii/licenta/.

Department of Communication, PR and Advertising, University of Cluj (2019) available at URL https://fspac.ubbcluj.ro/dcrpp/despre-noi/.

Faculty of Journalism and Communication, University of Bucharest (2019) available at URL http://www.fjsc.unibuc.ro/home/despre-noi.

Faculty of Social Sciences and Humanities, University of Sibiu (2019) available at URL https://www.ulbsibiu.ro/ro/facultati/facultatea-de-stiinte-socio-umane/.

Faculty of Communication and PR, SNSPA (2019) available at URL http://comunicare.ro/index.php?page=istoric.

Ivan, L., Daba-Buzoianu, C., Gray, B. (Eds.), Mapping Heterogeneity: Qualitative research in communication, Bucharest: Tritonic.

Jirak, J., Kopplova, B. (2008), Communication as an Academic Field: Eastern Europe and Russia. The international encyclopedia of communication.

Donsbach, W. (Ed). (2008), The International Encyclopedia of Communication. Blackwell.

Klyukanov, I. (2011), Russian Journal of Communication: A new journal on the block. Review of Communication, 11(3), 229-237.

Lindlof, T. R., Taylor, B. C. (2011), Qualitative communication research methods. Sage.

McQuail, D. (2008), Communication as an academic field: Western Europe. The International Encyclopedia of Communication. Malden MA: Blackwell, 638645.

Peruško, Z., Vozab, D. (2015), The Field of Communication in Croatia. Simonson, P., Park, D. W. (Eds.), The International History of Communication Study. Routledge. 213-235.

Sadlak, J. (1993). Legacy and Change. Higher Education and Restoration of Academic World in Romania. Technology in Society, 15, 75-100.

Sfez, L. (2001), Interdisciplinarité et communication. Cahiers internationaux de sociologie, 2, 341-349.

Simonson, P., Park, D. W. (Eds.) (2015), The International History of Communication Study, Routledge.

Taylor, B. C., Lindlof, T. R. (2013), Travelling methods: Tracing the globalization of qualitative communication research. Romanian Journal of Communication and Public Relations, 15, 3, 11-30.

Wang, G. (2011), Paradigm Shift and the Centrality of Communication Discipline. International Journal of Communication, 5, 9. 